\title{
The Impact Of Oil Production On Economic Growth In OPEC Countries: Evidence From The Panel Approach
}

Benanaya Djelloul, University of Djilali Bounamaa Khemis Miliana, Algeria Badreddine Talbi, National High School of Statistics and Applied Economics, Algeria

\begin{abstract}
This paper examines the causal relationship between oil production and economic growth in the Organization of the Petroleum Exporting Countries OPEC: Algeria, Angola, Ecuador, Islamic Republic of Iran, Iraq, Nigeria, Qatar, Saudi Arabia, UAE, and Venezuela, with annual time series data, from 1994 to 2013. A panel cointeration approach is suitable technique to examine oil production -economic growth nexus. Empirical results show that oil production variable and economic growth are cointegrated for these countries. Furthermore, we find by FMOLS approach and $P M G$ model that for the panel as a whole there are statistically significant feedback effects between these variables which supports the energy conservation policies as a policymaker.
\end{abstract}

Keywords: Oil Production; Economic Growth; Panel Data, FMOLS, PMG, OPEC Countries

\section{INTRODUCTION}

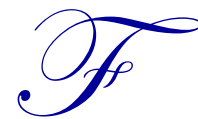

or the time being, the importance of oil production as the main source of energy has waned to some extent, due to the appearance of alternative forms of energy such as wind, water, and solar power. In spite of this, the importance of oil exceeds economic aspects and affects social life and welfare in general. For that reason, the perception among economists is that there is a strong relationship between the economic growth of a country and oil-production as a policymakers. In particular what form this relationship takes, and how it might be modified, Latife Ghalayini (2011).

The study of the energy-consumption and economic growth nexus has been a longstanding theme, both in the energy economics literature and in the energy policy debate. Although the large number of studies, involving different authors, countries, time periods, and econometric methodologies, the complex nature of the causality relationship deserves further research. Currently, there is no clear support regarding the direction, or even the existence of causality in the energy-growth nexus, Yildirim et al., 2014; Ozturk, 2010; and Apergis and Payne, 2009. Literature on oil production and oil and energy consumption, as well as the attention of analysts and policymakers has become progressively more interested in the nature of their links with economic performance, in particular with economic growth.

A large volume of studies on the dynamics of natural resources suggests that oil production have considerable consequences and effects on economic growth. These consequences are expected to be different in oil importing and in oil exporting countries, while an oil price increase should be considered good news in oil exporting countries and bad news in oil importing countries, the reverse should be expected when the oil price decreases. The transmission mechanisms through which oil production have an impact on real economic growth.

The purpose of this paper is to examine if economic growth can be explained by changes in the oil production. The paper is organized as follows: section 2 presents the methodology and data. Section 3 reviews the panel co integration test. The empirical part and tests are presented in section 4 to finally conclude in section 5 . 


\section{METHODOLOGY AND DATA}

In this study, the relationship between oil production and economic growth for the 1994 and 2013 periods was analyzed by Pedroni panel cointegration method, and then estimated by FMOLS estimator in oil exporting countries :( Algeria, Angola, Ecuador, Islamic Republic of Iran, Iraq, Nigeria, Qatar, Saudi Arabia, UAE, and Venezuela) Data consist of 20 years annually for each country and were taken from the World Bank's World Development Indicators and the International Energy Agency's statistics 2013. GDPper represents the natural logarithm of per capita GDP with constant 2005 us; Oilpro represents the natural logarithm of oil production we test both (in thousand barrels and tonne). Pedroni discussed the small sample properties of his cointegration test and concluded that the test tends to become overly conservative in the finite sample in which cross section dimension exceeds the time series dimension. There are many examples in the literature which used these methodologies in small samples such as Laurin, Apergis and Payne, Fernandez, Osbat and Schnatz, Melike Elif Bildirici, Fazll Kayıkç (2013).

In order to investigate the possibility of panel cointegration, it is first necessary to determine the order of integration before using cointegration techniques. For this purpose; we used Im,Pesaran and Shin test, which is being used intensively in panel unit root tests studies. IPS allows for heterogeneity both in intercept and slope terms for the cross section units and solves the serial correlation problem. Although the IPS test requires a balanced panel, it is the test most often used in practice because it is simple and easy to use The IPS unit root equation:

$$
\mathrm{y}_{\mathrm{it}}=\mathrm{p}_{\mathrm{i}} \mathrm{y}_{\mathrm{i}, \mathrm{t}-1}+\sum_{\mathrm{j}=1}^{\mathrm{p}_{\mathrm{i}}} \varphi_{\mathrm{ij}} \Delta \mathrm{y}_{\mathrm{i}, \mathrm{t}-\mathrm{j}} \mathrm{z}_{\mathrm{it}}^{\prime} \mathrm{Z} \gamma+\varepsilon_{\mathrm{it}}
$$

Null hypothesis states that all series in the panel have unit root and alternatively part of the series is stationary. It proposes an alternative test procedure that depends on the averages of individual unit root test statistics.

There may emerge cross section dependence problem as a consequence of unaccounted residual interdependence, regional and macroeconomic linkages, unobserved common factors and externalities. Although IPS do not consider this, new generation panel unit root tests account for the cross section problem by accepting the prevalence of macroeconomic linkages. Melike Elif Bildirici, Fazıl Kayıkç (2013ı).

\section{PANEL COINTEGRATION TEST}

In this step, we preceded to panel cointegration tests after the specification of order of integration for the series. Pedroni test is the most popular among panel cointegration tests. Pedroni also takes into account heterogeneity by using specific parameters which are allowed to vary across individual members of the sample. The Panel cointegration test, which allows for cross section interdependence with different individual effects, is specified as follows:

$$
\text { GDPper }_{\text {it }}=\alpha_{\mathrm{i}}+\delta_{\mathrm{t}}+\beta_{1 \mathrm{i}} \text { Oilpro }_{\text {it }}+\varepsilon_{\mathrm{it}}
$$

Where, $\mathrm{i}=1, ., \mathrm{N}$ for each country and $\mathrm{t}=1, . \mathrm{T}$ for each period, $\alpha_{\mathrm{i}}$ and $\delta_{\mathrm{t}}$ are country and time fixed effects respectively. $\varepsilon_{i t}$ show the estimated residuals. It is a test of the null hypothesis of cointegration for all cross section units against the alternative of no cointegration for at least one unit. However, Westerlund himself, argues that this test is subject to size distortions especially when the number of time series units is less than 100 . Joyeux and Ripple also point out that the results of the Pedroni test are more reliable than the Westerlund's test in small samples.

\section{EMPIRICAL RESULTS}

\subsection{Panel Unit Root Tests}

Panel unit root and stationarity tests have become extremely popular and widely used over the last decade. We used Im, Pesaran and Shin W-stat (IPS) test (1997 and 2003), Levin, Lin and Chu (2000), Breiting (2000). We also included panel stationarity test developed in Hadri (2000), results indicated that that null hypothesis of unit root cannot be 
rejected for the variables in levels. We further applied the unit root test in the first differences of the variables and the results reject the null hypothesis, implying that the levels are non-stationary, and the first differences are stationary.

Table 1. Panel Unit root tests results

\begin{tabular}{|c|c|c|c|c|c|c|c|c|}
\hline \multirow{3}{*}{ Variables } & \multicolumn{4}{|c|}{ GDPper } & \multicolumn{4}{|c|}{ Oilpro } \\
\hline & \multicolumn{2}{|c|}{ In levels } & \multicolumn{2}{|c|}{ First difference } & \multicolumn{2}{|c|}{ In levels } & \multicolumn{2}{|c|}{ First difference } \\
\hline & Statistic & $\operatorname{Prob}^{. * *}$ & Statistic & $\operatorname{Prob}^{* * *}$ & Statistic & $\operatorname{Prob}^{* * *}$ & Statistic & Prob $^{* * *}$ \\
\hline Levin, Lin \& Chu $\mathrm{t}^{\mathrm{a}}$ & -0.26332 & 0.3962 & -5.88311 & 0.0000 & -1.78849 & 0.0368 & -9.58382 & 0.0000 \\
\hline Im, Pesaran and Shin W-stat ${ }^{c}$ & 2.62308 & 0.9956 & -5.31936 & 0.0000 & 0.13481 & 0.5536 & -7.74748 & 0.0000 \\
\hline ADF - Fisher Chi-square & 12.4311 & 0.9004 & 64.3 & 0.0000 & 18. & 39 & 91.7 & 0.0000 \\
\hline PP - Fisher Chi-square & 22.9174 & 0.2929 & 64.4080 & 0.0000 & 15.3301 & 0.7572 & 96.4679 & 0.0000 \\
\hline Breitung t-stat ${ }^{b}$ & 0.87254 & 0.8085 & -3.16311 & 0.0008 & -0.77873 & 0.2181 & -6.71203 & 0.0000 \\
\hline Hadri Z-stat ${ }^{\mathrm{d}}$ & 8.11234 & 0.0000 & -0.26522 & 0.6046 & 8.10885 & 0.0000 & 0.81390 & 0.2079 \\
\hline Heteroscedastic Consistent Z-stat & 7.64200 & 0.0000 & 1.36165 & 0.0867 & 6.61654 & 0.0000 & 2.25573 & 0.0120 \\
\hline
\end{tabular}

${ }^{\mathrm{a}, \mathrm{b}}$ Null: Unit root (assumes common unit root process).

${ }^{\mathrm{c}}$ Null: Unit root (assumes individual unit root process).

${ }^{\mathrm{d}}$ Null Hypothesis: Stationarity

** Probabilities for Fisher tests are computed using an asymptotic Chi -square distribution. All other tests assume asymptotic normality.

According to computed of differences panel unit root tests values presented in Table 1, hypothesis of a unit root cannot be rejected for all variables in levels. The results further suggest that taking first differences remove these roots from the series implying that all individual series are integrated of order 1(I(1)).

We conclude that all methods are telling that DGPper and Oilpro variables have become stationary after the first difference.

\subsection{Pedroni Test and Johansen Fisher Panel Cointegration Test}

To determine whether a cointegrating relationship exits, the recently developed methodology proposed by Pedroni and Johansen Fisher panel cointegration are employed. Firstly we used four panel statistics which are v-statistic, $p$ statistic, PP-statistic and ADF-statistic (within dimension) and three group panel statistics which are group p-statistic, group PP-statistic and group ADF-statistic (between dimension) to test the null hypothesis of no cointegration against the alternative hypothesis of cointegration. These statistics are distributed asymptotically as standard normal. Secondly, we also conduct the Johansen fisher test to confirm that the existence of co integration between variables. The results are reported in Tables 2 and 3.

Table 2. Pedroni panel cointegration test

\begin{tabular}{l|c|c|c|c|c|c|c}
\hline \multicolumn{7}{c}{ Within Dimension Test Statistics } & \multicolumn{2}{c}{ Between Dimension Test Statistics } \\
\hline & Statistic & P-value & Statistic & P-value & & Statistic & P-value \\
\hline Panel v-Statistic & 1.250104 & 0.1056 & 0.019921 & 0.4921 & Group rho-Statistic & 0.980053 & 0.8365 \\
\hline Panel rho-Statistic & -0.869415 & 0.1923 & -0.386372 & 0.3496 & Group PP-Statistic & -2.341451 & 0.0499 \\
\hline Panel PP-Statistic & -2.364860 & 0.0090 & -2.332682 & 0.0098 & Group ADF-Statistic & -3.301534 & 0.0005 \\
\hline Panel ADF-Statistic & -2.644928 & 0.0041 & -3.841119 & 0.0001 & & \\
\hline
\end{tabular}

Table 3. Johansen Fisher Panel Cointegration Test

\begin{tabular}{l|c|c|c|c}
\hline \multicolumn{1}{|c|}{ No. of CE(s) } & trace test & P-value & max-eigen test & P-value \\
\hline None & 57.62 & 0.0000 & 47.67 & 0.0005 \\
\hline At most 1 & 32.14 & 0.0418 & 32.14 & 0.0418 \\
\hline
\end{tabular}

Table 2 reports both the within and between dimension panel cointegration test statistics for each panel data set. These statistics are based on averages of the individual autoregressive coefficients associated with the unit root tests of the residuals for each country in the panel. The majority of all seven panel cointegration tests reject the null hypothesis of 
no cointegration at the $5 \%$ significance level for the panel. Consequently, the evidence suggests that in both panel data sets there is a long run equilibrium relationship between oil production variable and economic growth. The result of coitegration test in table 3 indicates that all variables are cointegated. Johancen fisher panel cointegration test results confirmed that there is a long run cointegration relationship among the panel variables.

\subsection{FMOLS, DOLS and PMG Estimation Results}

We consider estimation of FMOLS and PMG estimators for the cointegration vectors as in table 4. (Phillips and Moon, 1999; Pedroni, 2000; Kao and Chiang, 2000; Mark and Sul, 2003). Both FMOLS and PMG are two important methods in panel techniques data which are proposed respectively by Pedroni $(1996,2000)$ and Pesaran, Shin, and Smith (1999). The first one focuses on the relationship between the differences of the regressors and the error term, taking into consideration the existence of the constant term. The second one aims to analyze the correlation between longrun and short-run coefficients in relation to error correction and error variances. The results of both set reports in the Table 4.

Table 4. Panel estimation FMOLS, DOLS results

\begin{tabular}{c|c|c}
\hline Panel A. & $\begin{array}{c}\text { Panel Fully Modified Least Squares } \\
\text { (FMOLS) }\end{array}$ & $\begin{array}{c}\text { Panel Dynamic Least Squares } \\
\text { (DOLS) }\end{array}$ \\
\hline OILpro & Dependent Variable GDPper & Dependent Variable GDPper \\
\hline T-statistics & 0.505304 & 0.561689 \\
\hline -value & $(6.724870)$ & 5.449982 \\
\hline$R^{2}$ & 0.0000 & 0.0000 \\
\hline
\end{tabular}

Panel B. Panel estimation $P M G$ results.

Dependent Variable: GDPper Explanatory Variable
Pooled Mean Group (PMG)

Coefficient

\begin{tabular}{l|c}
\multirow{2}{*}{ OILpro } & Long Run coefficients \\
& \multicolumn{1}{c}{0.847978} \\
\hline & $(0.0000)$ \\
\hline Error correction & Short Run coefficients \\
\hline D(GDPper(-1)) & $-0.167894(0.0503)$ \\
\hline D(GDPper(-2)) & $0.325554(0.0195)$ \\
\hline D(OILpro) & $-0.004066(0.9460)$ \\
\hline D(OILpro(-1)) & $0.309910(0.0003)$ \\
\hline Number of observation & $-0.113749(0.2282)$ \\
\hline P - value are in parentheses & $0.219654(0.0872)$ \\
\hline
\end{tabular}

According to the results presented in tables 3 and 4, FMOLS and DOLS results suggest that oil production has positive effect on the economic growth. With respect to the magnitudes of coefficients, results indicate that the oil production variable is positively related to economic growth $(+0.505),(+0.561)$ respectively and the coefficients are statistically significant. Otherwise, the error correction from the PMG estimator is significant with a value of negative 0.16 . This suggests that around $16 \%$ of the deviation from long-term relationship is corrected in the first year. The long run coefficient of oil production (OILpro) is positive and significant. The PMG estimates suggest a strong positive relationship among oil production and economic growth in the long run. The magnitude of the oil production variable coefficient is approximately 0.85 . Effectively, in average, a $1 \%$ increase in oil production leads to a $.85 \%$ increase in long run GDP per-capita. Hence, our results from estimated panel cointegration and PMG procedure suggest a positive long run relationship between oil production in OPEC countries and economic growth over the period of 1994 to 2013. 


\section{CONCLUSION}

This paper investigates the cointegration and causality relationship of oil production and economic growth in the OPEC countries: Algeria, Angola, Ecuador, Islamic Republic of Iran, Iraq, Nigeria, Qatar, Saudi Arabia, UAE, and Venezuela from the period of 1994 to 2013. To examine this relationship, we use two step procedures, in first step; we explore panel cointegration test by the Pedroni cointegration analysis and Johansen Fisher panel cointegration test. Both Pedroni panel cointegration test and Johansen Fisher test results show that oil production and economic growth are cointegrated. Secondly we employ a FMOLS, DOLS and PMG techniques to test the causal relationships between these macroeconomics variables. The results suggest that there has been a significant demand for oil production which has positive effect on the economic growth. Respect to the magnitudes of coefficients in OPEC countries. The empirical results of this study provide policymakers a better understanding of oil production- economic growth to formulate energy policies in these countries. Effectively, a $1 \%$ increase in oil production leads to $0.505 \%, 0.561 \%$ and $0.85 \%$ respectively an impact in long run gross domestic product per capita for these countries. Otherwise, the error correction from the PMG estimator is significant with a value of negative 0.16 . This suggests that around $16 \%$ of the deviation from long-term relationship is corrected in the first year.

\section{AUTHOR BIOGRAPHIES}

Benanaya Djelloul is a lecturer of Economics at University of Djilali Bounaama, Khemis Miliana, Algeria. His research topics include Time Series, Applied Economics, Econometrics and Modelling of Macroeconomics.

Badreddine Talbi is a lecturer of Economics at National High School of Statistics and Applied Economics of Algeria. His research topics include Applied Economics, Development Economics and Statistics.

\section{REFERENCES}

Al-Mulali U., Binti C.N., \& Sab C. (2012). The impact of energy consumption and CO2 emission on the economic growth and financial development in the Sub-Saharan African countries. Energy, 39(1), 180-186.

Alessandro C., \& Matteo M. (2014). On the economic determinants of oil production Theoretical analysis and empirical evidence for small exporting countries. Energy Economic, 44, 68-79.

Anca M. Cotet, Kevin K. (2013). Tsui, oil, growth, and health: what does the cross-country evidence really show? Journal of Economics, 115(4), 1107-1137.

Apergis N., Payne J.E. (2009). Energy consumption and economic growth: evidence from the Commonwealth of Independent States. Energy Economics, 31(5), 641-647.

Apergis N., Payne J.E. (2010). Renewable energy consumption and growth in Eurasia. Energy Economics, 32(6), $1392-1397$.

Barros, C.P., Gil-Alana, L.A., \& Payne, J.E. (2011). An analysis of oil production by OPEC countries: Persistence, breaks, and outliers. Energy Policy, 39(1), 442-453.

Hjalmarsson, E. \& Österholm, P. (2007). Testing for Cointegration Using the Johansen Methodology when Variables are NearIntegrated. International Monetary Fund, WP, 141.

Harri, R. (2002). Oil production responses to price changes: an empirical application of the competitive model to OPEC and nonOPEC countries, Energy Economics, 24(2), 97-106.

Im, K.S., Pesaran, M.H., \& Shin, Y. (2003), Testing for unit roots in heterogeneous panels. Journal of Econometrics, 115(1), 5374.

Fuinhas, J.A. (2015). Oil-Growth Nexus in Oil Producing Countries: Macro Panel Evidence. International Journal of Energy Economics and Policy, 5(1), 148-163.

Ghalayini, L. (2011). The Interaction between Oil Price and Economic Growth Economic Department, Middle Eastern Finance and Economics, 13, 127-141.

Hossain, S. (2012). Multivariate Granger Causality between Economic Growth, Electricity Consumption, Exports and Remittance for the Panel of Three SAARC Countries. Global Journal of Management and Business Research, 12(4), 41.

Bildirici, M.E., Kayikci, F. (2013). Effects of oil production on economic growth in Eurasian countries: Panel ARDL Approach. Energy, Volume 49(1), 156-161.

Neary, P. \& Van Wijnbergen, S. (1986). Natural resources and the macroeconomy. Cambridge, Mass., Oxford: Blackwell; MIT Press.

Pedroni, P. (1999). Critical values for cointegration tests in heterogeneous panels with multiple regressors. Oxford Bulletin of Economics and Statistics, 61(S1), 653-670.

Pedroni, P. (2001). Fully modified OLS for heterogeneous cointegrated panels. Advances in Econometric, 93-130. 
Pedroni, P. (2004). Panel cointegration; asymptotic and finite sample properties of pooled time series tests with an application to the purchasing power parity hypothesis. Econometric Theory: Cambridge University Press, 20, 597-325.

Pedroni, P. (2001). Purchasing power parity tests in cointegrated panels. Review of Economics and Statistics, 83(4), 727-731.

Pesaran, M.H., Shin. Y., \& Smith, R.J. (1999). Pooled mean group estimation of dynamic heterogeneous panels. Journal of the American Statistical Association, 94(446), 621-634.

Pesaran, M.H. (2007). A simple panel unit root test in the presence of cross-section dependence. Journal of Applied Econometrics, 22(2), 265-312.

Pesaran, M.H. (2004). General diagnostic tests for cross section dependence in panels. Cambridge working paper in economics, CWPE: 0435 .

Ratti, R.A \& Vespignani, J.L. (2015). OPEC and non-OPEC oil production and the global economy. Energy Economics, 50,364 378.

Westerlund, J. (2006). Testing for panel cointegration with multiple structural breaks. Oxford Bulletin of Economics and Statistics, 68(1), 101-132. 